\title{
THE MINDFUL SEON HWADU: SISIMMA AS A HEALING UTILITY; ITS EFFICACY FOR AD/HD AND BEYOND
}

\author{
Jay J. CHOI, M.D., DABPM ${ }^{1}$, Ph.D. B. Hyun CHOO ${ }^{2}$ \\ Former Associate Professor of Clinical Anesthesiology, \\ UMD New Jersey Medical School, Newark, $\mathrm{NJ}^{1}$ \\ Lecturer of Department of Asian and Asian-American Studies, \\ Stony Brook University, Humanities 1036, Stony Brook, NY ${ }^{1}$ \\ SUA, \\ Email: doctorjaychoi@yahoo.com ${ }^{1}$ \\ bhyun.choo@stonybrook.edu ${ }^{1}$
}

\begin{abstract}
Mindfulness meditation (MM), as revealed in the Satipatthāna, has become a useful alternative treatment modality for Attention Deficit Hyperactivity Disorder (AD/HD). MM is empirically based, attending areligiously to sensations and thoughts. However, its applicability has not reached its full efficacy due to its being transformed and truncated. We describe how the Seon hwadu, Sisimma can enhance its effectiveness, when coupled with Satipatțāna through the process of "tracing back the radiance." By accepting the nature of $A D / H D$ as that of a proactive asset, the mindful hwadu, Sisimma, can lessen the symptomatology of $A D / H D$, preserving its positives: spontaneity, persistence, and inspiring an experience of ultimate enlightenment. We discuss how Sisimma can contribute to mindfulness science, and enhance its efficacy as a treatment modality for AD/HD.
\end{abstract}

Keywords: Mindfulness Meditation; Attention Deficit Hyperactivity Disorder; Satipaț̣̂āna; Mindful Seon hwadu Sisimma; Korean Ganwha Seon;

\section{INTRODUCTION}

Stimulant medications, prescribed for attention deficit hyperactivity disorder (ADHD) in children and its adult equivalent, attention deficit disorder (ADD), have shown to be generally safe and effective in reducing the symptoms of $\mathrm{AD} / \mathrm{HD}^{1}$. However, despite ample evidence for the short-term benefits of medication and behavioral therapy, researchers are uncertain as to the relative merits after the acute 2- to 3- month span of most studies. The medications do help about $40-70 \%$ of those who use the drugs, but some researchers believe that the effectiveness of medication declines and disappears after a certain period. Therefore, due to growing disenchantment with the various treatment modalities for $\mathrm{AD} / \mathrm{HD}$, it makes sense that efforts to further explore $\mathrm{AD} / \mathrm{HD}$ treatment modalities, such as meditation, are expected and justified.

Mindfulness Meditation (MM) is known to enable the mind to remain calm and settled without distraction, and proponents of MM have claimed it to be an effective alternative treatment modality. The experience of MM and related teachings has been attributed to the Buddha and his subsequent practitioners. Although MM, as revealed in the Satipațthana

\footnotetext{
${ }^{1} \mathrm{AD} / \mathrm{HD}$ will be expressed in this article to describe both ADHD and ADD.
} 
Sutta $^{2}$ or Discourse on the Foundations of Mindfulness, is an essential practice through which the Buddha was said to have attained the ultimate enlightenment, its technique may be seen as nonreligious or areligious as it is empirically-based, rather than focusing on a deity or God. The practitioner simply pays close attention to his/her bodily sensations, feelings and specific thoughts. For this reason, intellectual resistance has been minimal on the part of Western medicine in employing the mindfulness modality; indeed, over the last 15 years there has been an impressive increase in public interest and scientific research on mindfulness, with over 3000 scientific publications having been produced on the topic since $1980 .^{3}$

At first sight, it may appear contradictory to attempt to teach mindfulness to people with $\mathrm{AD} / \mathrm{HD}$ since the core issue of $\mathrm{AD} / \mathrm{HD}$ is difficulty in paying attention, and mindfully meditating necessitates a sufficient ability to control one's attention by developing a steadfast awareness of the present moment. However, although MM has the potential for limitless expansion of its applicability, it appears to have not reached sufficiently its full efficacy due to a truncation of the original practice.

Myriads of descriptive features of meditative concentration, samādhi, have circulated among practitioners and scholars, some of which present a confused understanding of the experiences encountered as well as its range of meditation techniques. While mindfulnessbased practices have been proven effective under various clinical conditions, the use of Chan/Seon/Zen meditation, especially huatou or hwadu, by itself has not been considered beneficial as a treatment modality as it is construed simply as a distraction from or inattention to the source of suffering. The Chinese term huatou (K. hwadu) means the "head of speech," or the "apex of speech." (Further details in chapter 5.1.) Some Satipatthāna (P. the Foundation of Mindfulness) practitioners find that MM itself may not readily induce deep concentration, while on the other hand some Chan/Seon/Zen practitioners consider the huatou as too abstract. In order to provide a bridge for relevant transition, we describe here the Chan/Seon hwadu, Sisimma, via the method of "tracing back the radiance," which was popularized by the renowned Korean Seon master, Chinul. ${ }^{4}$

Both the Satipatthanna and the Sisimma require retaining concentration while awake and alert; the difference is in the method of concentration, which utilizes bare attention for the former and questioning for the latter. When the meditator arouses and holds the Sisimma in his/her mind, he/she traces the radiance back to its source, restoring the mind to its natural enlightened state. The resulting resonance is certainly remindful of the inductive, empiristic practice of Satipatțāna. Notably, it can be said that the Buddha's practice of Satipatțanna has evolved into a new version of mindful hwadu Sisimma in the Korean Seon tradition.

We propose a meeting point of the two practices, mitigating the weakness and enforcing the strength of each tradition, that is, maintaining the questioning of the Sisimma advancing to the status of an "emotionalized and sustained doubt," while being mindful of thoughts, feelings, and sensations without interruption in a non-judgmental way.

\footnotetext{
${ }^{2}$ Satipatțhāna Sutta (Discourse on the Foundations of Mindfulness) appears in two versions in the Pāli canon: (1) A long account known as the Mahāsatipațthāna Sutta in the Dīgha Nikāya, Ch. 22, Maurice Walshe, Wisdom Publications, Boston, 1995, pp. 335-350; (2) A slightly shorter text called the Satipatthāna Sutta in the Majjhima Nikāya, Ch 10, Ñāṇamolí and Bodhi, Wisdom Publications, Boston, 1995, pp. 145-155.

3 D.S. Black, Mindfulness journal publications by year, 1980-2014, 2015 . Retrieved from https://goamra.org/resources/ 2017

${ }^{4}$ Robert E. Buswell, Jr., Tracing Back the Radiance: Chinul's Korean Way of Zen, University of Hawaii Press, Honolulu, 1992, pp. 103-104.
} 
Specifically, one can view the various characteristics of AD/HD proactively utilizing as assets, and capitalize on them instantly by employing this novel technique of the mindful Seon hwadu, Sisimma, through which it can become coupled with the mindfulness of Satipatțhana. By taking advantage of the symptomatology of $\mathrm{AD} / \mathrm{HD}$ and preserving its positive qualities - spontaneity, boundless energy, and resilient persistence - we proffer a possibility that one can ironically reach an advanced level and even approach an experience of an ultimate enlightenment of a Buddhist kind. What is the ultimate enlightenment of a Buddhist kind, then? While a broad overview of Buddhist meditation lies beyond the scope of this article, we will discuss how mindfulness practice coupled with the Sisimma can be successfully applied to $\mathrm{AD} / \mathrm{HD}$ and further inspire one to an experience of awakening for the relief of all suffering. One may inquire at this point: among the various health issues, why has $\mathrm{AD} / \mathrm{HD}$ been singled out here as a focus?

\section{AD/HD IS A NEUROBEHAVIORAL DISORDER WITH HEAVY SOCIO- ECONOMIC IMPACT}

Researchers from the Centers for Disease Control and Prevention (CDC) have conducted extensive analyses to estimate the prevalence of parent-reported $\mathrm{AD} / \mathrm{HD}$ diagnosis, as well as current medication treatments for U.S. children/adolescents aged 4 to 17 years..$^{5}$ They demonstrated that in $2011,11 \%$ (6.4 million) of children/adolescents had received an AD/HD diagnosis. Previous results from surveys in 2003 and 2007 found that $7.8 \%$ (4.4 million) and 9.5\%, respectively were reported to have been diagnosed with $\mathrm{AD} / \mathrm{HD}$. Among those with a history of $\mathrm{AD} / \mathrm{HD}, 83 \%$ were reported as currently having $\mathrm{AD} / \mathrm{HD}$; furthermore, $69 \%$ of children with $\mathrm{AD} / \mathrm{HD}$ were taking medication $(6.1 \%, 3.5$ million children). The parent-reported history of $\mathrm{AD} / \mathrm{HD}$ increased by $42 \%$ from 2003 to 2011 with an average annual increase of approximately 5\%. More than two-thirds of those with current $\mathrm{AD} / \mathrm{HD}$ were taking medication in 2011, demonstrating the increasing burden of this disorder on the U.S. health care system. The CDC concluded that stronger efforts to further understand $\mathrm{AD} / \mathrm{HD}$ diagnostic and treatment patterns were warranted.

Although $\mathrm{AD} / \mathrm{HD}$ reportedly carries no risk for incurring other conditions or diseases, it is known that children with ADHD are likely to experience a range of co-existing conditions: learning disabilities, antisocial behavior, bipolar disorder, substance abuse, sleep disorders, and so forth. Treatment plans and medications can be both expensive and stressful. A study on the economic impact of childhood and adult $\mathrm{AD} / \mathrm{HD}$ in the United States $^{6}$ claimed that the annual price of treating a person with $\mathrm{AD} / \mathrm{HD}$ is $\$ 14,576$, costing Americans 42.5 billion dollars each year; this is a conservative estimate. Overall national annual incremental costs ranged from $\$ 143$ to $\$ 266$ billion. Most of these costs were incurred by adults $(\$ 105 \mathrm{~B}-\$ 194 \mathrm{~B})$ compared with children/adolescents $(\$ 38 \mathrm{~B}-\$ 72 \mathrm{~B})$; the largest cost category was productivity and income losses $(\$ 87 \mathrm{~B}-\$ 138 \mathrm{~B})$ for adults, and health care $(\$ 21 \mathrm{~B}-\$ 44 \mathrm{~B})$ and education $(\$ 15 \mathrm{~B}-\$ 25 \mathrm{~B})$ for children. As we shall see, there exists even further issues of concern.

\footnotetext{
${ }^{5}$ Susanna N. Visser, et al., "Trends in the parent-report of health care provider-diagnosed and medicated attention- deficit/hyperactivity disorder: United States, 2003-2011", J Am Acad Child Adolesc Psychiatry 53(2014), pp. 34-46. e2. doi: 10.1016/j.jaac.2013.09.001. Epub 2013 Nov 21.

${ }^{6}$ J.A. Doshi, et al., "Economic Impact of Childhood and Adult Attention-Deficit/Hyperactivity Disorder in the United States", J Am Acad Child Adolesc Psychiatry, 51-10 (2012), pp. 990 - 1002.e2. DOI: http://dx.doi.org/10.1016/j.jaac.2012.07.008
} 


\subsection{Effectiveness of medications}

Stimulant medications prescribed for $\mathrm{AD} / \mathrm{HD}$ have shown to be generally safe and effective for more than 40 years in reducing the symptoms of $\mathrm{AD} / \mathrm{HD}$. There are a number of controlled studies of $\mathrm{AD} / \mathrm{HD}$ that compared the results of medicated and non-medicated children with behavioral therapy. The largest of the controlled studies, the Multimodal Treatment Study of AD/HD, treated 579 children for 14 months. ${ }^{7}$ The study found that those treated with stimulant medications had their symptoms significantly reduced, and the effect was more powerful than in those treated with behavioral therapy. Despite ample evidence concerning the short-term benefits of medication and behavioral therapy, uncertainty has continued among providers and researchers as to the relative merits of behavioral and medication treatments. Some researchers believe that the effectiveness of medication declines and disappears when it is taken longer than two years. ${ }^{8}$ Although the medications have shown to help about $40-70 \%$ of those who use the drugs, about $90 \%$ experienced serious side effects during the first 6 months of use, which tapered off to about $15 \%$ after 2 years. For these reasons, it appears that efforts to further understand AD/HD diagnostic and treatment patterns beyond medications, such as MM, are justified, and needed. What, then, is $\mathrm{MM}$ and how does it work?

\section{MINDFULNESS MEDITATION AS A THERAPEUTIC ALTERNATIVE}

A national survey conducted in the United States in 2008 showed a marked increase in the number of people meditating, with approximately 10 percent of the population having some experience with meditation. ${ }^{9}$ The National Center for Complementary and Alternative Medicine describes meditation as a mind-body method, and includes it among interventions that employ a variety of techniques designed to focus attention and to facilitate the mind's capacity to affect bodily function and symptoms. The mindfulness form of meditation (MM) instructs the individual to become mindful of thoughts, feelings, and sensations and to observe them in a non-judgmental way. Practitioners generally believe that MM results in a state of calmness, physical relaxation, and psychological balance. ${ }^{10}$ Mindfulness is defined by Jon Kabat-Zinn as "the awareness that arises by paying attention on purpose, in the present moment, and non-judgmentally." 11 He stresses that as it is also defined as heartfulness, it may be viewed as beyond conceptual knowing, a complementary form of intelligence, and more akin to wisdom. Scott Bishop, et al. proposed an operational definition of mindfulness as the self-regulation of attention on the immediate experience in the present moment, characterized by curiosity, openness, and acceptance. ${ }^{12}$ Ruth Baer, et al. have described mindfulness' five key component skills: observing, describing, acting with

\footnotetext{
${ }^{7}$ P. S. Jensen, et al., "Findings from the NIMH Multimodal Treatment Study of ADHD: Implications and Applications for Primary Care Providers", J Dev Behav Pediatr 22 (2001), pp. 60-73.

${ }^{8}$ Ibid.

${ }^{9}$ Patricia M. Barnes, et al., "Complementary and alternative medicine use among adults and children: United States, 2007”, Natl Health Stat Report (2008), pp. 1-23.

${ }^{10}$ The National Center for Complementary and Alternative Medicine (NCCAM), http://nccam.nih.gov/ accessed on January 2018.

${ }^{11}$ Jon Kabat-Zinn, Full Catastrophe Living, Using the Wisdom of Your Body and Mind to Face Stress, Pain, and Illness, Bantam Books, NY, 2013 (1990), p. xxxv.

${ }^{12}$ Scott R. Bishop, et al., "Mindfulness: A proposed operational definition", Clinical Psychology: Science and Practice 11-3 (2004), p. 232.
} 
awareness, nonjudging of inner experience, and nonreactivity to inner experience. ${ }^{13}$ KabatZinn was among the first to study the effects of meditation on chronic pain. ${ }^{14} \mathrm{He}$ used the practice of MM in a 10-week Stress Reduction and Relaxation Program to train 51 chronic pain patients who had not improved with traditional medical care. After 10 weeks, $65 \%$ of the patients showed a reduction of greater than or equal to $33 \%$ in the mean total Pain Rating Index and $50 \%$ showed a reduction of greater than or equal to $50 \%$. Significant reductions in mood disturbance and psychiatric symptomatology accompanied these changes and were relatively stable on follow-up. Kabat-Zinn concluded that this form of meditation can be successfully used as the basis for an effective behavioral program in self-regulation for chronic pain patients. He postulated that meditation practice seemed to cause an uncoupling of the sensory dimension of the pain experience from the affective evaluative alarm reaction and thus to reduce the experience of suffering via cognitive reappraisal. Since then, nearly all other studies have been follow-ups to his work. However, how effectively can mindfulness meditation train the AD/HD mind to better concentrate and maintain focus?

\subsection{Using mindfulness meditation to train the $\mathrm{AD} / \mathrm{HD}$ mind}

The core issue of $\mathrm{AD} / \mathrm{HD}$ is difficulty with paying attention and controlling impulsive reactions. On the surface, it may seem contradictory to teach mindfulness to people with AD/HD. MM claims to improve one's ability to control the attention, while allowing one to be more aware of his/her emotional state, thus restraining one from reacting impulsively and replenishing one's self-regulation. Technically, the key is being aware of where one's attention is focused while one is engaged in routine activities. When one first practices mindfulness, he/she discovers how busy the mind is; this may be even more striking for someone with $\mathrm{AD} / \mathrm{HD}$. A UCLA researcher, Lidia Zylowska, et al., who operates the $\mathrm{AD} / \mathrm{HD}$ program at the UCLA Mindful Awareness Research Center, says that the basic practice is simply focusing on the sensation of breathing in and breathing out. ${ }^{15}$ As soon as one notices that he/she is thinking of something else, the instruction is to refocus one's attention on the breath. It goes without saying that the nature of the mind is to be distracted. Mindful awareness is not about how to breathe per se, but rather about returning to the breath immediately, when the mind wanders away. In this situation, it is important to note that the moment of catching oneself as distracted is in itself a moment of mindful awareness. Zylowska, et al. observing a group of twenty-four adults and eight teens with AD/HD, noted significant pre- to post-training improvements in self-reported symptoms of AD/HD. ${ }^{16}$ Improvements in both attention span and hyperactivity continued for three months after the training was completed. This study corroborates the effectiveness of MM on AD/HD. An emphasis on re-shifting one's attention, outwitting the mind's natural tendency to wander, is what makes this technique especially useful to someone suffering from AD/HD. This is the basis of the operation of $\mathrm{MM}$ for $\mathrm{AD} / \mathrm{HD}$.

\footnotetext{
${ }^{13}$ Ruth A. Baer, et al., "Construct validity of the five facets mindfulness questionnaire in meditating and nonmeditating samples", Assessment 15-3 (2008), p. 329. doi: 10.1177/1073191107313003.

${ }^{14}$ Jon Kabat-Zinn," "An outpatient program in behavioral medicine for chronic pain patients based on the practice of

mindfulness meditation: Theoretical considerations and preliminary results", General Hospital Psychiatry, 4-1, (1982), pp. 33-47.

${ }^{15}$ Lidia Zylowska, et al., "Mindfulness Meditation Training in Adults and Adolescents with Attention Deficit Hyperactivity Disorder: A Feasibility Study”, Journal of Attention Disorders 11-6 (2008), pp. 737-746.

${ }^{16}$ Ibid.
} 
Meditative techniques can often be categorized into two forms: those that emphasize concentration, such as mantra-based techniques, transcendental meditation (TM) and Chan/Seon/Zen meditation, and those that emphasize mindfulness, such as mindfulnessbased stress reduction (MBSR) and mindfulness-based cognitive therapy (MBCT). Both practices describe a unique attitude or intention associated with the manner in which focused attention is applied, emphasizing differing aspects of meditation practice: concentration requires mental activity, whereas mindfulness emphasizes non-activity.

Typically, standardized programs of MM consist of weekly meetings for 8 weeks, each lasting 2 to 2.5 hours, with an additional 6-8 hour retreat on a weekend day during the 8week training. MBCT maintains an 8 -week course length, similar to MBSR, but it is modified for the particular condition of each individual. MBCT uses traditional cognitive behavioral therapy and integrates it into a newer psychological strategy, MM. The Buddhist meditative practice of mindfulness is meant to promote greater awareness of one's self and environment by developing mindfulness skills, called awareness meditation or, in the Buddhist context, Vipassana meditation. Vipassana is the original practice from which mindfulness-based techniques are derived. The characteristic technique of mindfulness may not necessarily be religious or spiritual as it employs paying close attention on an empirical basis to one's bodily sensations, feelings and thoughts of a special kind, which means simply developing a greater awareness of what transpires in the present moment.

For these practical reasons, supported by a recent wave of scientific results, the practice of mindfulness has become easily acceptable without much resistance in modern intellectual society. However, how possible is viewing the original concept of mindfulness as used by the Buddha through the use of modern rational approach?

\subsection{Scientific evidence supports the effect of mindful awareness}

There is evidence supported by research that meditation practice can protect the prefrontal cortex - the area affected in $\mathrm{AD} / \mathrm{HD}$ and responsible for executive functions. For example, Sara W. Lazar, et al. demonstrated that long-term meditators have developed thicker pre-frontal brain regions, which are related to attention, self-monitoring, and emotional processing, when compared to the average person. ${ }^{17}$ Another study by Britta Hölzel et al. showed increases in gray matter after an eight-week MBSR course. In this study, the regions that showed changes are known to play a role in learning and memory, processing emotions, thinking about one's self, and the ability to adopt diverse perspectives. ${ }^{18}$ Michael R. Hagerty, et al. produced the first neural recording during ecstatic meditations (called jhanas) and tested to determine whether the brain reward system plays a role in the experience of joy. ${ }^{19}$ They found that the jhanas are altered states of consciousness that imply the following major brain changes based on subjective reports: (1) external awareness dims (2) internal verbalizations fade (3) the sense of personal boundaries is altered (4) attention is highly focused on the object of meditation and (5) joy increases to high levels. The fMRI and EEG results in the eight advanced meditations from an experienced meditator showed changes in brain activity in 11 regions; these changes

\footnotetext{
${ }^{17}$ Sara W. Lazar, et al., "Meditation Experience Is Associated with Increased Cortical Thickness", Neuroreport 16-17 (2005), pp. 1893-1897.

${ }^{18}$ Britta K. Hölzel, et al., "Mindfulness Practice Leads to Increases in Regional Brain Gray Matter Density", Psychiatry Research 191-1(2011), pp. 36-43.

${ }^{19}$ Michael R. Hagerty, et al., "Case Study of Ecstatic Meditation: fMRI and EEG Evidence of Self-Stimulating a Reward System”, Neural Plasticity, Article ID 653572, (2013), http://dx. doi. Org /10.1155/2013/653572
} 
occurred promptly after jhana was entered. In particular, extreme joy is associated not only with activation of cortical processes, but also with activation of the specific area in the dopamine/ opioid reward system. These researchers demonstrated an apparently novel method of self-stimulating the brain reward system using only internal mental processes, in which the transition to jhana is associated with selective increases of signals in the right temporal region and decreases in the parietal lobe and posterior frontal lobe.

However, as Chiesa and Malinowski acknowledged, despite its growing popularity, there remains uncertainty as to what mindfulness exactly is and inconsistency as to how it is taught. ${ }^{20}$ What limits the therapeutic value of MM in clinical settings? What seems to be the root cause of this limitation and how do we deal with it to maximize a potential benefit?

\section{MINDFULNESS IN CLINICAL SETTINGS: A TRUNCATED REPRESENTATION OF TH BUDDHA'S PRACTICE OF SATIPATTTHĀNA}

Since their inception in the 1980's, when mindfulness-based practices were first utilized to target particular conditions (such as Kabat-Zinn's MBSR program for chronic pain), their use in diverse adult clinical conditions has been expanded to the use of MBCT for other stress-related conditions such as anxiety, depression, stress/distress, as well as the following mental health-related issues: inattention, substance use, poor eating habits, sleep, pain issues, and so forth.

However, those practices appear to be predominantly focused on solving problems related to particular clinical conditions rather than on understanding the original motivation for their practice in early Buddhism, let alone on cultivating the essential qualities for the perfection of mindfulness. There seems to be the general presumption, widely accepted among academicians, that anything related to religion is non-scientific and thus unintelligent. Thus, such a truncated collection of heterogeneous mindfulness programs fundamentally neglects an understanding of what mindfulness was created for and how it can be correctly practiced to actualize the entire spectrum of MM. A legitimate question can be raised: Is it acceptable to approach Buddhism, especially the original concept of mindfulness as taught by the Buddha, through the filter of a modern scientific, rational approach? We opine that current mindfulness practice needs to emphasize not only the quality of awareness, but to also adequately reflect its intended purpose as revealed in early Buddhism. However, most mindfulness interventions do not clearly elucidate it as described in the Pali Canon, but merely indicate how MM can be utilized in a clinical setting. Although this article evaluates the health effects of MM programs on $\mathrm{AD} / \mathrm{HD}$, one needs to be reminded that MM was neither necessarily practiced for specific health benefits in early Buddhism, nor for philosophical enlightenment. For the Buddha, the goal was principally that sentient beings be relieved from all suffering, which is described evidently to be the essence of the Buddha's enlightenment.

Physical pain is only a part of all the suffering in life. As the issue of the Buddha's enlightenment exceeds the scope of our discussion here, this paper will not exhaustively explore the fundamental goal of meditation in general, but instead focus on its non-religious aspect within the scope of its health benefits for those suffering from $\mathrm{AD} / \mathrm{HD}$.

\footnotetext{
${ }^{20}$ Albert Chiesa and Peter Malinowski, "Mindfulness-based approaches: are they all the same?" J Clin Psychol 67-4 (2011), pp. 404-24.
} 


\subsection{Limit of clinical meditation programs as an effective therapeutic modality}

Despite its popularity as an effective therapeutic modality, there is a varying degree of evidence of the effects of meditation programs. After reviewing 18,753 citations, Madhav Goyal, et al. demonstrated that MM programs of 8 weeks indicated moderate evidence in improving anxiety, depression, and pain; low evidence in improving stress/distress and a mental health-related quality of life; and low or insufficient evidence of any effect on mood, attention, substance use, eating habits, sleep, and weight. ${ }^{21}$ The studies do point to a critical issue; the reasons for the lack of a significant reduction of stress-related health behavior outcomes may have involved the method used by the researchers, the difficulties of acquiring such skills or meditative states, and the limited duration of the programs. It needs to be recognized that mind training in awareness of a non-judgmental kind requires obviously diligent effort and takes a rather long period of time to master. However, many of the studies included in the Comparative Effectiveness Review were short-term (e.g., 2.5 hours a week for 8 weeks). Further, those studies appear to have been predominantly focused on solving physical or mental health-related conditions independent of understanding the motivation for mindfulness practice in early Buddhism. Herein a critical question may be raised: Is it necessary to become a Buddhist in order to practice a full-scale MM for the purpose of alleviating AD/HD? One of the underlying reasons mindfulness has become popular seems to have generated from the general presumption, especially among academicians and clinicians, that mindfulness has no correspondence with Buddhism as a religion. This may be in accord with the idea that anything related to religion may be construed to be illogical, irrational, and thus unintelligent. For these reasons, an employment of such heterogeneous mindfulness programs limits the rightful understanding of the purpose of mindfulness. At this point, a legitimate question can be raised: Is it possible to employ MM while avoiding being categorized as a Buddhist? Would this jeopardize the scholarly tradition of being rational and logical?

\subsection{Mindfulness is areligious and aspiritual}

Is mindfulness areligious and aspiritual at its base? Here, the terms, areligious and aspiritual, are not simply meant to be nonreligious and nonspiritual, but rather to transcend being religious and spiritual. Can modern intellectuals comfortably accept the idea of an areligiocity of Buddhism? Perhaps so, but can they do this without compromising the Buddha's original teaching? Probably not. Can Buddhist practice areligiously alleviate the suffering of physical pain and psychological stress? We can hopefully say yes. Alan Watts, while raising the crucial issue wherein Buddhism differs from Hinduism, emphasized Buddhism's nonreligious and nonspiritual characteristics:

Buddhism has no idea and no concept of God because Buddhism is not interested in concepts, it is interested in direct experience only. -- It does not believe in an immortal soul or seek any solace in any idea of life after death. The real thing in Buddhism, which is called nirvana, is sort of equivalent to moksa, or liberation. Nirvana means 'blow out'- the sigh of relief. -- Buddhism is saying that you do not need any gizmos to be in the know. You do not need a religion. You do not need any Buddha statues, temples, Buddhist rosaries, and all that jazz. ${ }^{22}$

\footnotetext{
${ }^{21}$ Madhav Goyal, et al., "Meditation Programs for Psychological Stress and Well-being: A Systematic Review and Meta-analysis", JAMA Intern Med. 174-3 (2014), pp. 357-368.

${ }_{22}$ Alan Watts, Buddhism, The Religion of No-Religion: the edited transcripts, Charles E. Tuttle Company. Rutland,

VT, 1996, pp. 6-8.
} 
Stephen Batchelor, a former ordained Buddhist monk known for his agnostic and secular approach, describes the Buddha not as a mystic, but as a savior. ${ }^{23}$ The Buddha saw himself as a healer, presenting his truths in the form of a medical diagnosis, prognosis, and treatment. The Buddha spoke of having discovered complete freedom of heart and mind from the compulsions of craving; he called this "the taste of dharma." 24 Batchelor may turn out to be an exemplar of the typical modern Western mindset. In his Confessions of a Buddhist Atheist, he focuses principally on the early teachings of the Buddha as found in the Pali Canon, and writes from the perspective of a committed layperson who seeks to lead a life that embodies Buddhist values within the context of secularism and modernity, while having no interest in preserving the dogmas and institutions of traditional Asian forms of Buddhism. ${ }^{25}$ Jon Kabat-Zinn goes even further with his stance on non-religiosity:

Mindfulness is an ancient Buddhist practice, which has profound relevance for our present-day lives. This relevance has nothing to do with Buddhism per se or with becoming a Buddhist, but it has everything to do with waking up and living in harmony with oneself and with the world. ${ }^{26}$

Kabat-Zinn adds that the key to this path lies at the root of Buddhism, Taoism, and yoga, and is also found in the works of people like Emerson, Thoreau, and Whitman, and even in Native American wisdom. ${ }^{27}$ It is simply the art of conscious living with an appreciation for the present moment and the cultivation of an intimate relationship through a continual attending to it. He claims that one does not have to be a Buddhist or a yogi to practice mindfulness.

Herein, there is a critical missing point in these scholarly intellectuals' remarks concerning MM. Is the nonreligious aspect of Buddhism excessively emphasized in order to justify truncating the Buddha's original intent in Satipațthāna, thus limiting its full capacity as a potential therapeutic modality? Shouldn't MM be understood more as of an "areligious" and "aspiritual" nature rather than simply being labeled nonreligious and nonspiritual? The answer would be a resounding Yes!

\subsection{Clinical mindfulness programs overlook the Buddha's utmost concern: suffering and its remedy}

Why do clinical practitioners neglect to give appropriate emphasis to the Satipațthana, which is essential in realizing the true nature of corporeality, feelings, mental formations and reality patterns? This issue will be examined by addressing a subtle difference between the ultimate concerns of the Buddha and those of the clinical mindfulness practitioners, respectively. The Buddha's primary concern was the issue of suffering and how to overcome it. Specifically, the goal of the Buddha was a complete and permanent liberation from suffering, not merely the transient alleviation of physical or emotional pain. In clinical programs, however, the original Satipațthana practice in the process of its application has been modified by the individual concerns of the particular medical seeker. It appears from

\footnotetext{
${ }^{23}$ Stephen Batchelor, Buddhism Without Beliefs, A Contemporary Guide to Awakening, Penguin Group Inc., New York, 1997, pp. 5-6.

${ }^{24}$ The term has a wide range of meanings in Buddhism: truth, reality; phenomenon, element, mental factor; things,

quality, but the foremost meaning is that of the teaching delivered by the Buddha.

${ }^{25}$ Stephen Batchelor, Confession of a Buddhist Athesist, Random House, New York, 2011, pp. xi, $253-254$.

${ }^{26}$ Jon Kabat-Zinn, Wherever You Go, There You Are, Mindfulness Meditation in Everyday Life. Hyperion, New York, 1994, p. 3.

${ }^{27}$ Ibid., pp. 5-6.
} 
the various writings of both scholars and practitioners that the vital message of the Satipatthana Sutta has rarely been successfully transmitted in the mindfulness-based therapeutic meditations such as MBSR or MBCT. Rather, this message has often been sifted out or omitted altogether.

A typical elaboration of the Satipatthana practice is described in condensed form: the body, feeling, mind, and mental objects, experienced through the six sense faculties, but recognized as essentially empty (shünya). This places an emphasis on consequent unique transformation into an ultimate religious experience, non-Self. However, it seems apparent that the practitioners of mindfulness-based therapeutic meditation appear to eliminate this vital understanding of the Satipatthāna, minimizing its paramount centrality and bypassing its elaborate and empirical instructions, rather than addressing the foremost agenda of the cessation of suffering. Such an over-simplification of the Satipatthana may hardly be sufficient to inspire its original intent, which involves the removal of suffering (dukkha) by realizing its conditionality within the contexts of non-Self (anatta, insubstantiality) and absence of substance (anicca, impermanence). What was the primary object of the Buddha's search for the truth? To answer this, we will focus specifically on the Buddha's discourses as described in the Pāli Nikāya.

The Buddha affirmed categorically to the monks, "Bhikkhus, both formerly and now what I teach is suffering and the cessation of suffering." ${ }^{28}$ To achieve this goal the Buddha enumerated a threefold path of practice - moral discipline, concentration, and wisdom. Each stage functions as a building block, serving as a foundation for full enlightenment. The Buddha's threefold path of moral discipline, concentration, and wisdom within a single inseparable system represents his method which leads to perfect enlightenment. Although the clinical mindfulness practitioners have never stated outwardly that moral discipline is not necessary, it has been assumed implicitly that moral practice should be maintained within a religious domain, in which modern intellectuals are usually not particularly interested. The Buddha continued on to reify three stages of practice for the liberation from all suffering by the specific application of the Noble Eightfold Path. ${ }^{29}$ These stages embody the training that leads to the cessation of suffering. It was clear to the Buddha that the prevalence of suffering is due to the sentient being's subjection to the three roots of all evil, as represented by three unwholesome actions, viz. lust, hatred, and delusion. The stage of moral discipline eliminates lust. The stage of true concentration and mental culture conquers hatred. Finally, wisdom or right understanding, also called direct knowledge resulting from meditation, dispels all delusion. All these three types of training were promoted by the Buddha through the cultivation of constant mindfulness (sati), which is the basis of all earnest endeavors for enlightenment (Nibbana). Constant mindfulness needs to be present in every skillful or karmically wholesome thought-moment. Nyanaponika Thera acknowledges that Right Mindfulness represents the beginning as well as the culminating point of the Buddha's minddoctrine as it is the master key to knowing the mind, the perfect tool for shaping the mind, and the lofty manifestation of the achieved freedom of the mind, and is thus the culminating point. ${ }^{30}$ He rightfully calls The Foundations of Mindfulness as described in the Satipatthana Sutta, "the Heart of Buddhist Meditation" and even "the Heart of the Entire Doctrine." $\mathrm{He}$ stresses that this great Heart is in fact the center of all the blood streams pulsating through

\footnotetext{
${ }^{28}$ Nānamamolí and Bodhi, The Middle Length Discourses of the Buddha, p. 234.

${ }^{29}$ Right View (Understanding), Right Thought, Right Speech, Right Action, Right Livelihood (Living), Right Effort (Exertion), Right Mindfulness and Right Concentration of Mind.

${ }^{30}$ Nyanaponika Thera, The Heart of Buddhist Meditation, Samuel Weiser, Inc., York Beach, ME, 1988, p. 24.
} 
the entire body of the doctrine. ${ }^{31}$ The significance of Right Mindfulness is thus often manifested and emphasized in the Buddha's teaching.

As such, clinical mindfulness practice appears to have become sidetracked from the Buddha's primary concern for suffering and its remediation. This may constitute one rationale to suggest why some religious emphasis on moral practice may be meaningful and perhaps should be required among clinical mindfulness practitioners. This may sound apologetic, however, it may not be necessarily so at least from an empirically rational perspective. We should remember that the Buddha's original motivation in formulating the foundations of mindfulness as espoused in the Satipatthāna Sutta was ultimately to unfold the concept of non-Self. How do modern non-Buddhist intellectuals respond to this? How rationally can this seemingly apologetic issue be handled? What is the gist of the Satipațthāna to begin with? Now, a short survey of the Buddha's basic teachings needs to be outlined here, especially those pertaining to the Satipatțāna, the foundation of mindfulness.

\section{SATIPATTHĀNA, THE FOUNDATION OF MINDFULNESS}

As is written in the Pāli Nikāya, the Buddha practiced the Satipatthāna and attained the ultimate religious experience of enlightenment, Nibbanā (S. Nirvāna ), a final liberation from suffering. In the Satipatthāna-sutta or Discourse on the Foundations of Mindfulness, after his first-hand experience of enlightenment, the Buddha declares Satipatthana as the "direct path" (ekāyana maggo) that will lead directly to the realization of Nibbāna. According to Anāyalo, direct path is a translation of the Pāli expression ekāyano maggo, made up of the parts eka, "one", ayana, "going", and magga, "path". This can be understood as a "direct" path in the sense of leading straight to the goal; as a path to be travelled by oneself "alone"; as a path taught by the "One" (the Buddha). ${ }^{32}$ The Buddha avows that it is a single path, not a divided path; as a way that has to be walked by oneself alone, without a companion; and as a way that takes one to the goal, Nibbāna. ${ }^{33}$

In order to justify the efficacy of the medical implications of mindfulness-based interventions, major theoretical and conceptual developments need to be clearly understood. Buddhist scholars generally agree that the Satipatthana-sutta is one of the most widely commented upon texts in the Pâli canon and continues to hold a central place in the modern Vipassana movement. ${ }^{34}$ In the text, the Buddha is reported to have set forth the discourse under a fourfold rubric called the "Four Foundations of Mindfulness" (P. Satipatthāna), which are comprised of "contemplation of the body"; "contemplation of sensations," that is, physical sensations that are pleasurable, painful, or neutral; "contemplation of mind," in which one observes the broader state of mind or units in the ephemeral mind-stream of momentary duration; and "contemplation of mental objects" or factors of consciousness making up the respective states of mind, which involves the mindfulness of several key doctrinal categories, such as the five aggregates, the Four Noble Truths, and so forth. ${ }^{35}$ The central theme of Satipatțhana practice is insight into the true nature of the body, feelings, mind-states and reality-patterns (phenomena, mind-objects, or dhamma): this enables the practitioner to achieve a transformation through awareness by means of a rigorous

\footnotetext{
${ }^{31}$ Ibid., p. 7.

${ }^{32}$ Anālayo, Satipatțāna, The Direct Path to Realization, p. 27

${ }^{33}$ Nānamolí and Bodhi, The Middle Length Discourses of the Buddha, p. 1188.

${ }^{34}$ Robert E. Buswell, Jr. and Donald S. Lopez Jr., The Princeton Dictionary of Buddhism, Princeton University Press, Princeton, NJ, 2014, pp. 786-787.

${ }^{35}$ Ibid., p. 786.
} 
detachment. Specifically, the practice supports a sustained analysis resulting in the arising of wisdom into the true nature of reality, namely the three marks of all conditioned phenomena in samsāra: impermanence (P. anicca, S. anitya); suffering (P. dukkha, S. duhkha), and nonSelf (P. anattā, S. anātman). ${ }^{36}$

In the Satipatthana-sutta, being mindful of the body in the body is explained in the following six ways: mindfulness of breathing (ānappana-sati), the four postures (walking, standing, sitting, lying), clear awareness of all activities of the body, reflection on the repulsive parts of the body, analysis of the four bodily elements (earth, water, fire, and air), and the nine charnel ground contemplation. ${ }^{37}$ While one abides contemplating in the body, supreme insight is developed through being mindful of its arising and vanishing factors to the extent necessary for bare knowledge and awareness. In mindfulness of feeling, one recognizes three kinds of feelings: pleasant, unpleasant, or indifferent, and sees clearly their transitory quality. Supreme insight is developed similar to the contemplation of the body. In contemplation of mind, one remains mindful of every state of consciousness, whether the mind is possessed or not of the impulses of greed, hatred, or delusion. Supreme insight is developed similar to the contemplation of the body and feeling. How does a practitioner abide in the contemplation of mental objects? This is to be practiced in five areas with reference to the Five Hindrances, ${ }^{38}$ the Five Aggregates of Clinging, ${ }^{39}$ the Six Internal and External Sense-bases, ${ }^{40}$ the Seven Factors of Enlightenment, ${ }^{41}$ and the Four Noble Truths. ${ }^{42}$ Insight is to be developed in the same way as contemplating the body, feeling, and the mind. Nyanaponika Thera encapsulates precisely the entire Discourse on the Foundations of Mindfulness as "a comprehensive theoretical and practical instruction for the realization of that liberating truth of non-Self (anattā), having the two aspects of egolessness and voidness of substance." ${ }^{, 3}$ In psychological terms, Satipatthana appears to impart a type of de facto melting mechanism with regard to the ego formation, namely the dissolution of ego through cultivating penetrating insight. As the Dalai Lama states that the nature of non-Self is not a matter of something that existed in the past becoming nonexistent, the Self is to be understood as being never-existent right from the start. ${ }^{44}$ As Mark Epstein notes clearly, the actual target of Buddhist insight is not the ego in the Freudian sense, but rather the selfconcept, the representational component of the ego, or the actual internal experience of one's self. ${ }^{45}$ A great number of Buddhist texts exist, which contain innumerable resources of rich psychological information to support this view. Further details can be extracted from available publications. ${ }^{46}$

\footnotetext{
${ }^{36}$ Bodhi. The Noble Eightfold Path. Access to Insight,

http://www.accesstoinsight.org/lib/authors/bodhi/waytoend.html, Retrieved 11-12-2017.

${ }^{37}$ Ibid., pp. 145-155.

${ }^{38}$ Sense desire, anger, sloth \& torpor, agitation \& worry, and doubt.

${ }^{39}$ Material form, feeling, perception, mental formation, and consciousness.

${ }^{40}$ Eye-visible forms, ear-sounds, nose-smells, tongue-flavors, body-tactual objects, mind and mind-objects.

${ }^{41}$ Mindfulness, Investigation of reality, Energy, Rapture, Tranquility, Concentration, and Equanimity.

${ }^{42}$ Suffering, the origin of suffering, the cessation of suffering, and the path leading to the cessation of suffering. See the details in Nyanaponika Thera, The Heart of Buddhist Meditation, pp. 123-135.

${ }^{43}$ Nyanaponika Thera, The Heart of Buddhist Meditation, p. 75.

${ }^{44}$ Hopkins, Jeffrey and Napper, Elizabeth, (eds), Kindness, Clarity, and Insight: The Fourteenth Dalai Lama, His Holiness Tenzin Gyatso, Snow Lion Publications, Ithaca, NY, 1984, p. 40.

${ }^{45}$ Mark Epstein, Thoughts Without A Thinker, Psychotherapy From A Buddhist Perspective, Basic Books, New York, 1995, p. 98.

${ }^{46}$ Nānamolí and Bodhi, The Middle Length Discourses of the Buddha, p. 155. Also see Anālayo, Satipațthāna, The Direct Path to Realization, Windhorse Publications, Cambridge, UK, 2003, pp. 117-249.
} 
The methodical practice of Satipatthāna within the system of Buddhist meditation operates on the principle of initially developing calmness (P. samatha), which finally leads to insight (P. vipassana $)$. Here, the mental phenomena are analyzed and viewed in the light of the Three Characteristics: impermanence, suffering, and non-Self. ${ }^{47}$ The Majjhima Nikāya states repeatedly in the Discourse on Satipatthana that the Buddha is reported to have taught the systematic cultivation of Right Mindfulness as the most simple and direct method for training and developing the mind. For the Buddha, it was undoubtedly the most effective and thorough way for the ultimate deliverance from greed, hatred and delusion, known as the three poisons.

In summary, the primary aim of the Satipatthāna is to identify the nature of non-Self, thoroughly filtered through the practice of vipassana, and to authenticate it as being nonexistent from the start. As revealed in the Digha Nikāya, the Buddha emphasized the importance of the Satipatthana even in the words of his last days. He illustrated a detailed account of how a monk should live as "an island unto himself with the Dharma as an island" and the reason why:

Therefore, Ananda, you should live as islands unto yourself, being your own refuge, with no one else as your refuge, with the Dharma as an island, with the Dharma as your refuge, with no other refuge... Here, Ananda, a monk abides contemplating the body as body, earnestly, clearly aware, mindful and having put away all hankering and fretting for the world, and likewise with regard to feelings, mind and mind-objects... And those who now in my time or afterwards live thus, they will become the highest, if they are desirous of learning. ${ }^{48}$

The repetition of the phrase "contemplating the body as body, feelings as feelings," and so forth, is intended to impress upon the meditator the importance of remaining aware in sustained attention directed on a chosen object, and not straying into the field of a different contemplation. Mind (P. citta) in this context means a state of mind or unit within the ephemeral stream of the mind of momentary duration. Mental objects, dhamma, are the mental contents or factors of consciousness, making up the respective states of mind. The object of Right Mindfulness comprises the entire human being and one's entire field of experience. Simply put, the Satipatthāna consists of mindfulness of body $(k \bar{a} y a)$, feeling (vedana), mind (citta), and mental objects (dhamma) in that order. ${ }^{49}$ Further details can be extracted from available publications. ${ }^{50}$

\subsection{Psychology of non-attachment in the Satipațhāna: bare attention is an initial tool to unlocking the Satipațhāna as the key to realize non-Self.}

Mindfulness is the specific aspect of Bare Attention, which provides the key to the distinctive method of Satipatthana. Nyanaponika Thera sums up the general principle underlying the practice of Bare Attention:

Bare Attention is the clear and single-minded awareness of what actually happens in us, because it attends just to the bare facts of a perception as presented either through the five physical senses or through the mind which constitutes the sixth sense. Attention is kept to a bare registering of the facts observed, without reacting to them by deed, speech, or by mental comments. Any such comments arising in one's mind are made objects of Bare

\footnotetext{
${ }^{47}$ Nyanaponika Thera, The Heart of Buddhist Meditation, pp. 102-103.

${ }^{48}$ Maurice Walshe, The Long Discourses of the Buddha, p. 245.

${ }^{49}$ Ibid., pp. 335-350.

50 See R. L. Soni, The Only Way To Deliverance, pp. 19-26; Anālayo, Satipațthāna, pp. 117-249; U. Silananda, The Four Foundations of Mindfulness, pp. 13-25.
} 
Attention, and are neither repudiated nor pursued, but are dismissed, after a brief mental note has been made of them. ${ }^{51}$

However, the word "dismissed" may not precisely describe the method of Bare Attention because it implies an active meaning of reject or refuse. One does not actively dismiss the facts of perception, but rather simply lets go of them. It is like not chasing the fly away, but just letting it buzz off. As Nyanaponika Thera points out, this procedure as adopted in Buddhist meditation serves as a safeguard against the speculative interpretation of meditative experience. Why is it important to clarify the meaning of letting go? This term is used in the sense of relinquishing or renouncing and thus represents central themes that underlie the path to liberation from its outset to its final completion of literally letting go of any clinging whatsoever. ${ }^{52}$ What needs to be let go of in a deeper sense is control. Anālayo is right on the mark when he says that the desire to control is simply a manifestation of clinging to a sense of ' $I$ ', which means the sense of ownership towards goods and possessions. To gradually undermine this sense of ownership, letting go is repeatedly recommended in the early discourses. ${ }^{53}$ Letting go of grasping at one's possessions leads to generosity, which manifests in delighting in letting go in the sense of giving and sharing. This indicates that the benefit of such a letting go is the gain of the concentrative depth of the mind; eventually the sense of 'I' goes into abeyance, allowing for the subjective experience of a merger between the observing subject and the observed meditative object. ${ }^{54}$ Thus, letting go via the way of Bare Attention operates on a practical method for developing the non-attachment, which provides the key to the principle that tranquility (P. samatha) is initially developed which finally leads to insight (P. vipassanā).

One may wonder how to incorporate "letting go" practically into his/her daily life. Here is a hypothetical illustration of how Bare Attention may be practiced while meditating via the Satipatthāna: Imagine a practitioner jogging while being mindful of breathing (a kāya); $\mathrm{S} /$ he happens to fall into a thorny rose bush and pricks her/his face on a thorn. The practitioner remains mindful of feeling a sharp pain (a vedanā) from the swollen and bleeding wound. S/he may be aware of various thoughts such as anger or regret and may even begin cursing (a citta). Through mindfulness of mental objects, one recognizes clearly their ephemeral quality, devoid of ever-lasting substance, while also being mindful of their arising, abiding and vanishing aspects. While thus engaged, one's mind is settled, calm and detached, not clinging to the body (a dhamma).

As such, a supreme understanding of dependent origination may arise, accompanied by insight into the two aspects of non-Self: lack of ego and absence of substance. In daily life whenever feelings arise upon sense contacts with the surroundings, if these are mindfully monitored at a default setting, one will be led towards the transformation of the natural faculty of ordinary perception into the heuristic status of enlightenment. As Ayya Khema states, "Instinctively we are a constant reactor, but deliberately we become an actor." 55

Reviewing the kernel of the Satipatthāna, how can we optimize its practice for the full benefit of an entire spectrum of meditation without sacrificing the original Satipatthana

\footnotetext{
${ }^{51}$ Ibid., p. 30.

52 Anālayo, Excursions into the Thought-World of the Pāli Discourses, Patiyatti Publishing, Onalaska, WA, 2012 , p. 266.

${ }^{53}$ Ibid., p. 267.

${ }^{54}$ Ibid., pp. 267-268.

55 Ayya Khema, "Here and Now: Ten Dhamma Talks", Access to Insight, 25, III. Awake and Aware (2010), p. 16. https://www.accesstoinsight.org/lib/authors/khema/herenow.html.
} 
practice? We propose a unique coupling of the hwadu, Sisimma with the Satipatthana. This may appease the intellectual resistance on the part of modern intellectuals.

For now, a sketch of how mindfulness was practiced in early Buddhism, transformed in the Chan/Seon/Zen tradition, and amalgamated into a hwadu, Sisimma, will be briefly reviewed especially in the Korean Ganwha Seon practice,

\subsection{Transformation of the Satipațhāna in East Asian countries}

During its transmission from India to East Asian countries, the Satipațthāna in conveying its vital message to its followers may have subsequently infused its teaching into various traditions. The Chan tradition in particular adapted itself to the diverse propensities and indigenous nature of the various countries, especially in China, Korea, and Japan. What happened to the Buddha's "ekāyana maggo" in the Chan tradition? A search to establish a trace of the Satipațthāna in the Mahāyāna, and particularly the Chan tradition, reveals a scarcity of resources on this issue. One may wonder if its teaching has ever been sustained in the Mahāyāna tradition, especially the Chan tradition. If it has been preserved, what aspects of the Satipatthana formula are visible in the later traditions and in what particular form? While each Chan/Seon/Zen tradition will not be delineated in detail here, this paper will search for corresponding clues while tracing the Satipațthāna within Chan/Seon/ Zen tradition. We contend that the Mahāyāna tradition carried down some essence of Satipațthāna, but the Chan tradition in particular did not sufficiently give it as much emphasis as was taught by the Buddha. The practice appears rather faded, truncated, transformed or even excluded altogether, especially by the Tang (618-907) to later Song dynasty (960-1279) Chan practitioners. ${ }^{56}$ However, in the Korean Seon tradition the Satipatthāna, which is a prevailing key element of the Buddha's ekāyana maggo, had been re-positioned into one of the famous Ganhwa Seon hwadu, Sisimma, by the 14th century Seon Master Naong Hyegeun (1320-1376 CE) and many other influential Seon practitioners following him. ${ }^{57}$

In searching for a vestige of evidence of Satipațthāna in the Mahāyāna, particularly with regard to its transformation to the Sisimma, a bridging mechanism will be explored through the input of "tracing the faculty of hearing," as presented distinctively in one of the eighth century Chinese apocryphal scriptures, the Śüramgama Sūtra (The Sūtra of Heroic Progress). This Sütra is viewed as a redemptive feature in the Mahāyāna tradition, emphasizing the empirical nature through the sensory faculties, in which a particular path using the faculty of hearing is employed as a tool for enlightenment. Tracing the faculty of hearing has been popularized in the similar practice of "tracing back the radiance" in the Korean Buddhist tradition. The process referred to as "tracing back the radiance" 58 or "counter-illumination" 59 refers to turning the light inwards onto oneself, or turning one's attention, which is ordinarily directed to external things, back to reflect on one's original nature. The idea of tracing back the radiance has a long history, dating from early Buddhism through to Chinese Buddhism. It is to be remembered that in the Indian Buddhist meditative traditions the way of practicing tracing back the radiance was treated as one of the mindobject contemplations in the Satipatthāna-sutta; the meditator was taught simply to observe

\footnotetext{
${ }^{56}$ See details in John R. McRae, The Northern School and the Formation of Early Ch'an Buddhism, University of Hawaii Press, Honolulu, HI, 1986, pp. 235-253.

${ }^{57}$ HyungWoo Kim, 'Naong Hwasang' 懒翁和告, in Hangukbulgyo Inmulsasangsa, Minjoksa. Seoul, 1997, p. 258.

${ }^{58}$ Robert E. Buswell, Jr., Tracing Back the Radiance: Chinul's Korean Way of Zen, p. 104.

${ }^{59}$ John R.McRae, The Northern School and the Formation of Early Ch'an Buddhism, p. 114.
} 
the arising and vanishing of any mind-object, mindfully with bare attention in order to reach the insight that all things are impermanent. Although the mental technique of Satipatțanna from a psychological perspective can be related to tracing back the radiance, it was described implicitly in the Indian traditions, and not addressed explicitly as such.

\section{THE CONCEPT OF "TRACING BACK THE RADIANCE" IN THE KOREAN BUDDHIST TRADITION}

The Chan tradition in particular adapted itself to the diverse propensities and indigenous nature of the various countries, especially in China, Korea, and Japan. In the Korean Buddhist tradition, Bojo Chinul (1158-1210 CE) introduced his unique method of "tracing back the radiance" in Korea, and was the first teacher in Korea to advocate the use of $h w a d u$ in its formalized sense. ${ }^{60}$ Today in Korea, as Buswell notes, hwadu is the predominant technique cultivated in meditation halls, and almost all masters advocate its use for students at all levels. Chinul proposed a principal means for catalyzing an initial awakening through tracing the radiance emanating from the luminous core of the inner mind back to its source, restoring the mind to its natural enlightened state. This process indicates an awakening to the realization that one's original nature is not different from that of the buddhas. ${ }^{61}$ Here, it may be said that despite Chan's differing approach, wherein the Satipatthāna Sutta has been less emphasized, and perhaps even tacitly considered inferior, the message of through-the-sensation of the Satipațthāna Sutta was specifically communicated to Korean Buddhists by Chinul. A century or more later, the Buddha's original message of through-the-sensation in the Satipatthana was further emphasized by Naong Hyegeun (1320-1376 CE), who introduced the hwadu, Sisimma to his followers in Korea, while instilling its message with new meaning. The specific origin and evolution of the $h w a d u$, Sisimma is presented below.

\subsection{The evolution of kung-an / huatou: the Shishenmo}

The Chinese term huatou (K. hwadu, J. watō), which means literally the "head of speech," can be taken figuratively as the "apex of speech" or the "point beyond which speech exhausts itself." 62 It is a short holophrase, functioning as a phrase or sentence, often extracted as a concise summary of an entire encounter dialogue, kung-an (K. gong-an, J. koan) between a Chan master and an interlocutor passed down from earlier kung-ans, which is said to be conducive to enlightenment. This phrase becomes the subject of meditation and introspection in its own right, closely connected with the gist of the entire dialogue but is clearly representative.

The huatou can be described as equivalent to a computer keyboard shortcut, which is a way to invoke a function [the ultimate state of Great Enlightenment] in the computer [Buddhist practitioner] by pressing [breaking the final barrier of the rationalistic intellectual capacity] a combination of keys on the keyboard [focusing single-mindedly on a huatou]. The purpose of focusing on the huatou is to move the practitioner beyond the point of rationalization and conceptualization, thus enabling an experience of enlightenment. Kung-

\footnotetext{
${ }^{60}$ Robert E. Buswell, Jr. 'The Korean Approach to Zen', in The Collected Works of Chinul, University of Hawaii Press, Honolulu, HI, 1983, pp. 37-38.

${ }^{61}$ The Buddha signifies specifically the "enlightened Sage" of the Sākya Clan, Sākyamuni, whereas the buddha refers to one of many other buddhas as an "awakened one" or "enlightened one," as designated in the Buddhist literatures, particularly in the Mahāyānan tradition.

${ }^{62}$ Robert E. Buswell, Jr. "The Korean Approach to Zen”, in The Collected Works of Chinul, p. 67.
} 
an/huatou meditation has been increasingly popular in Asian Buddhist societies since the eighth century. Understandably, not all the same kung-an/huatou are used by practitioners in every country. Depending upon people's inclinations and customs, some kung-an/huatou have gained more popularity than others. Stuart Lachs lists a number of popular huatous which are commonly used among Chan/Seon/Zen practitioners in China, Korea, and Japan, respectively. ${ }^{63}$

In China it is well known that the most popular huatou is "Who is it that recites the name of the Buddha?" (Nianfo shishéi), that is, who recites the invocation to Amitābha Buddha? ${ }^{64}$ This particular huatou has been popularized by Xuyun (1840-1959 CE), the most famous Chan monk in the $19^{\text {th }}$ and $20^{\text {th }}$ centuries in China. In the Korean Seon, which is unlike the Chinese/Japanese traditions, the hwadu, "Sisimma" (C. shishenmo, J. zejinmo, What is it?) is certainly one of the most popular hwadus. ${ }^{65}$ This particular huatou, the Shishenmo is arguably one of the most famous huatous of the entire Kanhua Chan (questioning meditation) which traces its origin to the first encounter of the sixth patriarch Huineng (638-713 CE) and his disciple, Nanyue Huairang (677-744 CE), and has undoubtedly been one of the most popular hwadus in Korea ever since. Specifically, it first appears as a kung-an in the Platform Sutra of the sixth patriarch Huineng. ${ }^{66}$ Nanyue Huairang was one of Huineng's two disciples who were conferred the dharma transmission of mind-seal; the Chan lineage branched out into a number of sublineages thereafter. A historical anecdote of the huatou, Shishenmo begins when Nanyue Huairang first met Huineng as follows:

\footnotetext{
... Upon his arrival, and after the first salutation, Nanyue Huairang was asked by the Patriarch whence he came. 'From Sung Shan,' replied he. 'What thing is it (that comes)? How did it come?' asked the Patriarch. 'To say that it is similar to a certain thing is wrong,' he retorted. 'Is it attainable by training?' asked the Patriarch. 'It is not impossible to attain it by training; but it is quite impossible to pollute it,' he replied....Being thereby enlightened, Huairang realized intuitively what the Patriarch had said. ${ }^{67}$
}

In this particular scenario, however, the message of ultimate enlightenment disregards the relevancy of the sensations in an empirical sense, the observing of which is the key to the distinctive method of Satipatthana as taught by the Buddha. In the Korean Ganhwa Seon practice, however, in the earlier depiction of this encounter dialogue, Shishenmo evolved into the mindful hwadu Sisimma, which integrated the classical Sinitic Chan praxis with the spirit of Satipatthāna in a format of tracing back the radiance. In the Japanese Zen tradition, especially that of the Rinzai school, the two most popular koans are: "Mu" (nothing) and Hakuin's "What is the sound of one hand?"69 Peter Harvey speculates that the latter koan is

\footnotetext{
63 Stuart Lachs, "Hua-t'ou: A Method of Zen Meditation", Non-duality magazine 6, 2012, pp. 8-10, http://www.nondualitymagazine.org/nondualitymagazine.6/nonduality-magazine.6.contents.htm.

${ }^{64}$ Peter Harvey, An Introduction To Buddhism: Teaching, History and Practices, Cambridge University Press Cambridge, UK, 2013, p. 366.

${ }^{65}$ Lachs, "Hua-t'ou: A Method of Zen Meditation", pp. 8-10.

${ }^{66}$ T 2008:48.346b21-362b19

${ }^{67}$ A.F. Price, and Mou-Lam Wong, The Diamond Sutra and The Sutra of Hui Neng, Shambhala Publications, Inc., Berkeley, CA, 1969, pp. 75-76.

${ }^{68}$ Hakuin Ekaku (1685-1769 CE). A renowned Japanese Zen Master, Hakuin was a strong advocate of questioning meditation (J. Kanna Zen, K. Ganhwa Seon, C. Kanhua Chan), which focuses on the role of doubt in contemplating the koan. The contemporary Japanese Rinzai training system is attributed to Hakuin (Robert E. Buswell, Jr. and Donald S. Lopez Jr., The Princeton Dictionary of Buddhism, pp. 342-343.
} 
perhaps an allusion to the Zen understanding of viewing everything as a Oneness, or the Buddha-nature. ${ }^{70}$

\subsection{From Shishenmo to Sisimma in the Korean Seon tradition}

The $h w a d u$, Sisimma is especially significant in the Korean Seon tradition, in which the practice of Satipațthana has further evolved into a new version of hwadu, Sisimma, which recalls the Satipatthāna at its origin. Both the Satipatthāna and the Sisimma require a retaining of concentration when awake and alert, the difference being a bare attention for the former and questioning for the latter. In Korean Buddhist history, Naong Hyegeun (1320 $1376 \mathrm{CE}$ ) was known to be the first Seon Master who emphasized its importance. He was a famous Seon master in the late Koryeo period (918-1392) and one of the great authorities of Seon along with Taego Bowu (1301-1382 CE). ${ }^{71}$ Naong Hyegeun allegedly received dharma transmission, the so-called mind-seal, from a Chinese Chan master of the Linji line, Zhikong (?-1366), and firmly established the Ganhwa Seon (C. Kanhua Chan, questioning meditation) in Korea. ${ }^{72}$ Master Taego is revered as the father of the restoration of the Jogye Order of Korean Buddhism.

Ever since Naong introduced the Sisimma, its unique usage as one of the most famous hwadus has prevailed widely among most Korean Buddhist Seon practitioners up until the present day. These include Gusan Suryun (1909-1983 CE), Toeiong Seongcheol (19121993 CE), Seungsahn Haengwon (1927-2004 CE), Songdam Jeongeun (1929- ), and many more. Gusan was a renowned Korean Seon master, providing a wealth of practical teaching for students, particularly with regard to the unique Korean practice of Sisimma. He was the first Seon teacher to have accepted and trained Western students in a Korean monastery. His choice of hwadu, Sisimma is succinctly described in his book, The Way of Korean Zen. He emphasizes that the key factor is to maintain a constant sense of questioning, "emotionalized and sustained doubt," 73 and not just a simple repetition of the words. Having taken hold of the Sisimma, a student is advised to sustain the questioning: "What is seeing?" "What is hearing?" "What is smelling?" "What is moving the body?"and so on. Whenever the hwadu, Sisimma arises in the meditator's mind, s/he is to trace the radiance back to its source, and to restore the mind to its natural enlightened state. This is reminiscent of the inductive empiristic practice of Satipatthana. The process of questioning should continue uninterrupted, with each new question adding to the previous one, in an overlapping fashion. Maintaining a smooth and steady overlapping, the practitioner allows the emotionalized doubt to sustain itself continuously and with more intensity. When the mass of questioning grows to a critical point, it is said to suddenly burst and the entire universe is shattered. Finally, one's Original Nature then appears with various features. This is considered the beginning of the so-called Enlightenment, or awakened state. Gusan declares that when one experiences such a state, $\mathrm{s} /$ he should proceed to a qualified teacher to receive confirmation

\footnotetext{
${ }^{69}$ Yoel Hoffmann, The Sound of The One Hand, 281 Zen Koans with Answers, Basic Books, Inc., New York, 1975, pp. 47-54.

${ }^{70}$ Peter Harvey, An Introduction To Buddhism, p. 367.

${ }^{71}$ Y. K. Suh, "The History and Culture of Buddhism in the Koryŏ Dynasty", in The History and Culture of Buddhism in Korea. ed. The Korean Buddhist Research Institute, Dongguk University Press, Seoul, Korea, 1993, p. 166.

72 Jaeryong Shim, Korean Buddhism; Tradition and Transformation, Ji Moon Dang Publishing Co., Seoul, Korea, 1999, p. 153.

73 疑情Euijeong (C. yiqing); This refers to a constant state of intense questioning of the 'doubt - mass'. Some Buddhist scholars translate this literally as "sensation of doubt," but an "emotionalized and sustained doubt" may be rendered better than a sensation of doubt as a doubt itself is not sensible.
} 
of the level of awakening. ${ }^{74}$ The realization of such innate Oneness, or the Buddha-nature, transcending two extremes of dichotomy, would lead the practitioner to an ultimate enlightenment.

Among recent Seon masters, Songdam is worth mentioning with regard to the actual meditation technique of the $h w a d u$ practice. Songdam teaches his students to practice the meditation of counting the breath (K. susikgwan) before the actual hwadu practice of "What is it?" (Sisimma). ${ }^{75}$

\subsection{The practices of Satipațhāna and mindfulness of breathing}

Mindfulness of breathing ranks the highest place among the various subjects of Buddhist meditation and is known to be the most basic practice in Contemplation of the Body. It is particularly worth mentioning that mindfulness of breathing entails a very close observation of one of the essential functions of the body.

Among the various body functions, breathing is unique in that it is the only one in which some degree of voluntary alteration is possible during which the spontaneous aspect of breathing is being maintained involuntarily. Circulation, for example, with its rhythmic pumping of blood from the heart, is mainly an involuntary function. The Buddha seemed to have acknowledged such a characteristic of breathing in that he highly recommends the practice of being mindful of breathing, as described in the Majjhima Nikāya. ${ }^{76}$

In a practical setting, the Sisimma can be incorporated into one's daily activity employing the inductive and empirical method of the Satipatthana; this has been particularly emphasized by Korean Seon practitioners. When one attempts to be mindful of each breath attentively, only then does s/he begin to realize that the mind is being constantly distracted and scattered ubiquitously within the ordinary space-time frame, which leads to a state of disharmony and thus away from wholesomeness.

However, especially during the mindful practice of breathing the Sisimma can be an especially helpful reminder for sustaining awareness of mind. The question "What is it?" is to be maintained firmly in every moment of moving, abiding, sitting, lying, speaking, silence, and being tranquil. It creates an ambiance for the undivided attention or mindfulness that the practitioner needs to employ at each and every moment of breathing during all biological functions. With the help of the Sisimma, one can more easily learn to divert one's discursive attention and revert back to one's original nature through the practice of Satipatthāna; this can be an invaluable tool to alleviate the tendency of constant "popping and switching" the focus of attention in the clinical condition of AD/HD.

This practice may be beneficial for modern people who live in a complex environment and are prone to develop maladaptive behaviors such as the persistent pattern of AD/HD. It is generally believed among Korean Seon practitioners that if practiced profoundly and sufficiently, the practice of hwadu, Sisimma will eventually lead the practitioner to an ultimate enlightenment since all sentient beings are, at the core, preloaded with the buddhanature. It follows that this practice may be construed as a novel meeting point of the two practices, the Satipațthāna and the Chan tradition.

\footnotetext{
${ }^{74}$ Martine Batchelor, The Way of Korean Zen by Kusan Sunum, Weatherhill, Boston \& London, 2009, pp. 59-63.

${ }^{75}$ Songdam, "Hwalgu Chamseon Beop", Bulil Hoebo, July, 1988, pp. 445 \& 455.

76 Ñānamolí and Bodhi, The Middle Length Discourses of the Buddha, p. 943.
} 


\section{CONCLUSION}

Notably, stimulant medications prescribed for attention deficit hyperactivity disorder (ADHD) in children and its adult equivalent, attention deficit disorder (ADD) have shown to be generally safe and effective in reducing the symptoms of these disorders. However, it is known that these medications do help only about $40-70 \%$ of those who use the drugs, and the effectiveness of medication declines and disappears when it exceeds two years.

Due to growing disenchantment with the various treatment modalities for AD/HD, Mindfulness Meditation (MM) as revealed in the Satipatthāna, has emerged as an effective alternative treatment modality. Although the Satipațthāna was practiced by the Buddha in order to attain the ultimate enlightenment, its technique has been seen as nonreligious, rather areligious beyond being nonreligious, as it is empirically-based, involving close attention to one's bodily sensations, feelings and specific thoughts. For this reason, resistance has been minimal from Western medicine in employing this mindfulness modality, and its popularity has been supported by a recent wave of scientific studies. At first sight, it may appear contradictory to teach mindfulness to individuals with $\mathrm{AD} / \mathrm{HD}$ as the core issue in this condition is difficulty in paying attention, and mindfully meditating necessitates the ability to control attention by developing awareness of the present moment. MM's potential is limitless, but its applicability has not reached full efficacy due to the truncation of the original practice. While mindfulness-based techniques have been popular in various clinical conditions, Chan/Seon/Zen by itself has rarely been employed as a treatment modality. It has not been considered beneficial, being construed as a mere distraction or inattention. In order to provide a bridge for the nature of self-regulation, a special Chan/Seon hwadu, Sisimma may be introduced, utilizing the unique method of "tracing back the radiance," popularized by the renowned Korean Seon master Chinul. Thus, the practice of Satipatțāna has evolved into a new version of hwadu, "Sisimma" in the Korean Seon tradition. Both the Satipatthana and the Sisimma require the retaining of concentration when awake and alert, the difference being a bare attention for the former and questioning for the latter. Whenever the Sisimma arises in the meditator's mind, s/he is to trace the radiance back to its source, restoring the mind to its natural enlightened state. This resonates with the inductive, empirical practice of Satipatthāna. Through this complementary method, mindfulness practice coupled with the Sisimma broadens its effectiveness, rendering it easily applicable to the alleviation of $\mathrm{AD} / \mathrm{HD}$.

To indicate that the hwadu, Sisimma coupled with Satipatthana can enhance the effectiveness of MM, we propose herein a meeting point of the two practices, thus mitigating the weakness and improving the strength of each. In this way, the practitioner can maintain a questioning of the Sisimma, advancing to the state of an emotionalized and sustained doubt, while being mindful of thoughts, feelings, and sensations in a non-judgmental way without interruption. We have endeavored to focus on one of the most popular Chan/Seon hwadus, Sisimma, in relation to how it may be utilized along with mindfulness-based programs for individuals with $\mathrm{AD} / \mathrm{HD}$.

The main point here is that accepting the various perspectives regarding $\mathrm{AD} / \mathrm{HD}$, one may take those perspectives proactively as assets from the start and capitalize on them by employing the novel technique of the mindful Seon hwadu, Sisimma. Thus, the Sisimma can then be coupled or amalgamated into the mindfulness of Satipatthana in order to manage the negatives of $\mathrm{AD} / \mathrm{HD}$, and simultaneously to preserve the positives such as creativity, boundless energy, and persistence. We have attempted to provide an understanding of how to improve $\mathrm{AD} / \mathrm{HD}$ based on the experience of meditative concentration. This understanding 
may inspire one with an ultimate enlightenment of a Buddhist kind for the relief of all suffering in life. Building from this innovative effort, future research may uncover additional merits as an effective alternative treatment for $\mathrm{AD} / \mathrm{HD}$.

\section{REFERENCES}

[1] Anālayo, Satipațthāna, The Direct Path to Realization, Windhorse Publications, Cambridge, UK, 2003.

[2] Excursions into the Thought-World of the Pāli Discourses, Patiyatti Publishing, Onalaska, WA, 2012.

[3] _ Perspectives on Satipatthāna, Windhorse Publications, Cambridge, UK, 2013.

[4] Baer, Ruth A., Smith, Gregory T., Lykins, Emily, et al., "Construct validity of the five facets mindfulness questionnaire in meditating and nonmeditating samples", Assessment 15(3), (2008), p. 329, doi: 10.1177/1073191107313003.

[5] Barnes, Patricia M., Bloom, Barbara, Nahin, Richard L., "Complementary and alternative medicine use among adults and children: United States, 2007", Natl Health Stat Report (12) (2008), pp. 1-23.

[6] Batchelor, Martine, (trans), The Way of Korean Zen by Kusan Sunum, Weatherhill, Boston \& London, 2009.

[7] Batchelor, Stephen, Buddhism Without Beliefs, A Contemporary Guide to Awakening, Penguin Group Inc., New York, 1997.

[8] _ Confession of a Buddhist Athesist, Random House, New York, 2011.

[9] Bishop, Scott R., Mark Lau, Shauna Shapiro, et al., "Mindfulness: A proposed operational definition", Clinical Psychology: Science And Practice 11-3 (2004), p. 232.

[10] Black, David S., Mindfulness research publications by year, 1980-2014, (2014), Retrieved from American Mindfulness Research Association, https://goamra.org/ 2-2-2018.

[11] Buswell, Jr. Robert E., (trans), “The Korean Approach to Zen”, in The Collected Works of Chinul, University of Hawaii Press, Honolulu, HI, 1983.

[12] _ Tracing Back the Radiance: Chinul's Korean Way of Zen, University of Hawaii Press, Honolulu, HI, 1992.

[13]__ _ \& Lopez Jr. Donald S., The Princeton Dictionary of Buddhism, Princeton University Press, Princeton, NJ, 2014.

[14] Chiesa, Albert., Malinowski, Peter, Mindfulness-based approaches: are they all the same? J Clin Psychol 67 (4) (2011),pp.404-424.

[15] Choo, B. Hyun, “Can Seon Master Ven. Seungsahn's Four Suchness Measure the Buddhist Enlightenment?" in the International Journal of Buddhist Thought \& Culture 22, (2014), pp. 87-114.

[16] Doshi, Jalpa A., Hodgkins, Paul, Kahle, Jennifer, et al., "Economic Impact of Childhood and Adult Attention-Deficit/Hyperactivity Disorder in the United States", Journal of the

American Academy of Child \& Adolescent Psychiatry, 51-10, (2012), pp. 990 - 1002.

[17] Epstein, Mark, Thoughts Without A Thinker, Psychotherapy From A Buddhist Perspective. Basic Books, New York, NY, 1995.

[18] Goyal, Madhav, Singh, Sonal, Sibinga, Erica M.S., et al., "Meditation Programs for Psychological Stress and Well-being: A Systematic Review and Meta-analysis", JAMA Intern Med.174(3), (2014), pp. 357-368.

[19] Hagerty, Michael R., Isaacs, Julian, Brasington, Leigh, et al., "Case Study of Ecstatic Meditation: fMRI and EEG Evidence of Self-Stimulating a Reward System”, Neural Plasticity 3 (2013):653572, http://dx. doi. Org /10.1155/2013/653572-2-5-2018.

[20] Harvey, Peter, An Introduction To Buddhism: Teaching, History and Practices, Second edition, Cambridge University Press, Cambridge, UK, 2013.

[21] Hoffmann, Yoel, (trans), The Sound of The One Hand, 281 Zen Koans with Answers, Basic Books, Inc., New York, 1975.

[22] Hölzel, Britta K., Carmody, J., Vangel, M., et al., "Mindfulness Practice Leads to Increases in Regional Brain Gray Matter Density", Psychiatry Research 191- 1 (2011), pp. 36-43.

[23] Hopkins, Jeffrey and Napper, Elizabeth, (eds), Kindness, Clarity, and Insight: The Fourteenth Dalai 
Lama, His Holiness Tenzin Gyatso, Snow Lion Publications, Ithaca, NY, 1984.

[24] Jensen, Peter S., Hinshaw, Stephen P., Swanson, James M., et al., "Findings from the NIMH Multimodal Treatment Study of AD/HD (MTA): Implications and Applications for Primary Care Providers", J Dev Behav Pediatr 22, (2001), pp. 60-73.

[25] Kabat-Zinn, Jon, "An outpatient program in behavioral medicine for chronic pain patients based on the practice of mindfulness meditation: Theoretical considerations and preliminary results", General Hospital Psychiatry, 4-1, (1982), pp. 33-47.

[26]_ Wherever You Go, There You Are, Mindfulness Meditation in Everyday Life, Hyperion, New York, 1994.

[27]__ Full Catastrophe Living, Using the Wisdom of Your Body and Mind to Face Stress, Pain, and Illness, Bantam Books, New York, (1990), 2013.

[28] Khema, Sister Ayya, "Here and Now: Ten Dhamma Talks", Access to Insight, 25, III.

Awake and Aware. (2010)https://www.accesstoinsight.org/lib/authors/khema/herenow.html.

[29] Lachs, Sturt, "Hua-t'ou: A Method of Zen Meditation”, Non-duality magazine 6, (2012), pp.

$8-10$, http://www.nondualitymagazine.org/nondualitymagazine.6/nonduality-magazine.6.

contents.htm

[30] Lazar, Sara. W., Kerr, Catherine E., Wasserman, Rachel H., et al., "Meditation Experience Is

Associated with Increased Cortical Thickness", Neuroreport 16-17, (2005), pp. 1893- 1897.

[31] McRae, John R., The Northern School and the Formation of Early Ch'an Buddhism,

University of Hawaii Press, Honolulu, HI, 1986.

[32] Mochizuki, Sinko 望月信亨, (1977), Bulgyo Gyungjeon Seongnipsaron, Kim, Jinyeol, (trans),

Bulgyosidaesa, Seoul, Korea, 1995.

[33] Ñannamolí and Bodhi, (trans), The Middle Length Discourses of the Buddha, A New

Translation of the Majjhima Nikāya, Wisdom Publications, Boston, MA, 1995.

[34] Price, A. F. and Wong, Mou-Lam, The Diamond Sutra and The Sutra of Hui Neng, Shambhala

Publications Berkeley, CA, 1969.

[35] Shim, Jaeryong, Korean Buddhism; Tradition and Transformation, Jimoondang Publishing

Co., Seoul, Korea, 1999.

[36] Silananda, U., The Four Foundations of Mindfulness, Wisdom Publications, Boston, MA,

1990.

[37] Soka Gakkai, The English Buddhist Dictionary Committee, The Soka Gakkai Dictionary of

Buddhism, The Soka Gakka, Tokyo, Japan, 2002.

[38] Soma Thera, The Way of Mindfulness, The Satipatțhana Sutta and Commentary, Buddhist

Publication Society Kandy, Sri Lanka, 1975.

[39] Songdam, Hwalgu Chamseon Beop, Bulil Hoebo, July, (1988). pp. 445-455.

[40] Soni, R. L., The Only Way To Deliverance, Prajna Press, Boulder, CO, 1980.

[41] Suh, Yoon-kil, "The History and Culture of Buddhism in the Koryo Dynasty", in The History and Culture of Buddhism in Korea, (ed), The Korean Buddhist Research Institute, Dongguk University Press, Seoul, Korea, 1993.

[42] Visser, Susanna N., Danielson, Melissa L., Bitsko, Rebecca H., et al., "Trends in the parentreport of health care provider-diagnosed and medicated attention-deficit/ hyperactivity disorder: United States, 2003-2011”, J Am Acad Child Adolesc Psychiatry, Jan; 53(1) (2014), pp. 34-46. e2.doi: 10.1016/j.jaac.2013.09.001. Epub 2017 Nov 21.

[43] Walshe, Maurice (trans). The Long Discourses of the Buddha: A translation of the Digha Níkāya. Wisdom Publications, Boston, MA, 1995.

[44] Wang, Gene-Jack, Volkow, Nora D., Wigal, Timothy, et al., "Long-Term Stimulant Treatment Affects Brain Dopamine Transporter Level in Patients with Attention Deficit Hyperactive Disorder", PLoS ONE 8 (5) (2013), e63023. doi:10.1371/journal.pone.0063023.

[45] Watts, Alan, Buddhism, The Religion of No-Religion: the edited transcripts, Charles E. Tuttle Company, Rutland, VT, 1996.

[46] Zylowska, Lidia., Ackerman, Deborah L., Yang, May H., et al.. "Mindfulness Meditation Training in Adults and Adolescents with Attention Deficit Hyperactivity Disorder: A

Feasibility Study", Journal of Attention Disorders 11-6, (2008), pp. 737-746. 